\title{
On street parking and its impact on road performance
}

\author{
Sonya Sulistyono ${ }^{1, *}$, Harnen Sulistio ${ }^{1}$, Ludfi Djakfar ${ }^{1}$, Achmad Wicaksono $^{1}$, and Ririn \\ Endah Badriani ${ }^{2}$ \\ ${ }^{1}$ Brawijaya University, Department of Civil Engineering, Malang, East Java, Indonesia \\ ${ }^{2}$ Jember University, Department of Civil Engineering, Jember, East Java, Indonesia
}

\begin{abstract}
Commercial areas have a high economic and parking activity. High parking activity that is not comparable to the availability of parking facilities and it can interfere with the performance of the road. This study based on congestion caused by activities on-street parking on Gajah Mada St., Rambipuji, Jember. This road broadness reduced because on street parking and disrupting the flow of traffic. From the survey on Thursday, March 5, 2015 obtained the following results: performance comparison roads with and without on-street parking shows capacity has increased $25 \%$, DS decreased $25 \%$, and the speed has increased $11 \%$. Characteristics of the road parking for MC, LV and HV in order are: volume parking 257 vehicles, 62 vehicles, and 10 vehicles. Accumulated parking $46 \mathrm{veh} / \mathrm{h}, 20$ $\mathrm{veh} / \mathrm{h}$, and $5 \mathrm{veh} / \mathrm{h}$. Turn over parking $0,0997 \mathrm{veh} / \mathrm{SRP} / \mathrm{h}, 0,4588$ $\mathrm{veh} / \mathrm{SRP} / \mathrm{h}$, and 1,0940 veh/SRP/h. Parking index of 0,27, 2,22, and 8,20.
\end{abstract}

\section{Introduction}

Transportation requires parking space to stop. If parking is not well served, it can disrupt traffic flow and cause congestion. Parking problems that often encountered is parking on the side of the road. This type of parking will incur a loss for both the driver and the public, if not properly managed. Road parking leads to road reduction and a disruption to traffic performance.

This study was conducted to review the effect of parking on the road body on it performance, especially on Gajah Mada St., Rambipuji, Jember. This road is the center of economic activity with parking facilities that do not meet, so the road is used as a parking lot. This road is a national road with a fairly solid traffic reaching $49,491 \mathrm{veh} /$ day. The type of road on Gajah Mada is 2/2 UD with total length of road $1.3 \mathrm{~km}$. The effect of parking space usage on road performance is done along $100 \mathrm{~m}$ at the highest point of parking activity and traffic. The purpose of this research is to know the characteristics of parking on the road body that occurs, the comparison of road performance with and without the parking on the road body, and the influence of road parking on the road performance.

This study will approach the characteristics of parking and traffic characteristics such as research method [1] who have conducted research to obtain the results of road performance

* Corresponding author sonya.sulistyono@unej.ac.id 
comparison with and without road parking. Characteristic is a basic trait that can provide an assessment of the services and problems that occur in the study area. Traffic characteristics include capacity, degree of saturation, and travel speed. While parking characteristics include peak parking hours, parking volume, parking accumulation, turn over parking, average parking time, parking capacity, and parking index.

\section{Research methods}

\subsection{Location of study}

Gajah Mada St. has a total length of $1.3 \mathrm{~km}$. The object in this study is limited to $100 \mathrm{~m}$, i.e. at STA $0+700$ up to STA $0+800$ or segment between Light shirt store up to Gajah Mada Sport (see figure 1). Restrictions on research sites are useful to facilitate surveys conducted in the field

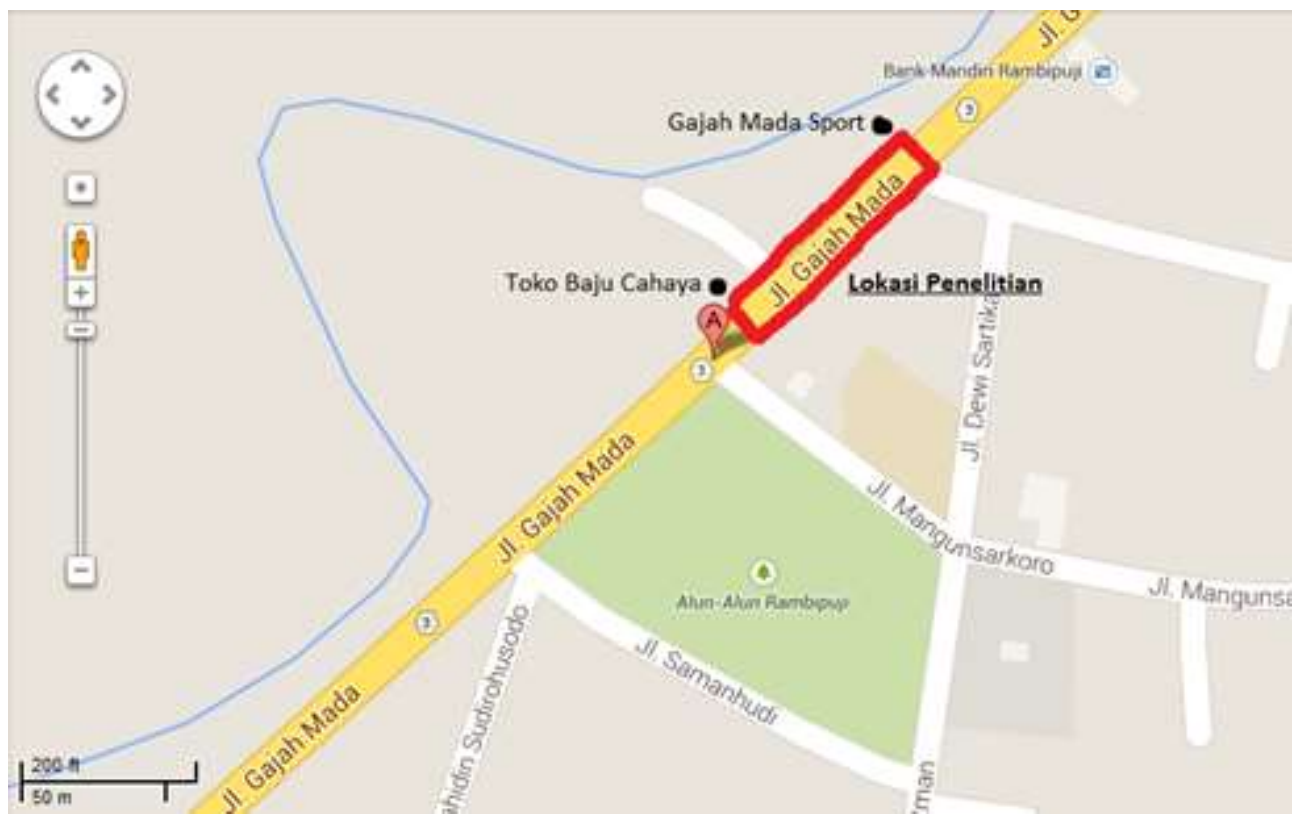

Figure 1. Location of study

\subsection{Research Steps}

The stages of the implementation of this study are as follows:

1. Initial stage. Identify the problems and analysis the existing conditions as needed. Based on the initial survey obtained parameters to be surveyed.

2. Planning phase. Planning the survey activities and run it systematically and not deviate from the problem. In the stage of determining the method and time of the survey.

3. Data collection phase. Conducted by collecting data by way of direct survey in the field. Surveys include: inventory surveys, traffic surveys, and parking characteristics surveys.

Data analysis phase. The analysis includes: analysis of traffic performance, analysis of parking characteristics, and analysis of the effect of parking on traffic performance. 


\section{Result and discussion}

\subsection{Road inventory}

Inventory data is needed to support the data in the road performance analysis. Gajah Mada St. is the primary collector road. Type of Gajah Mada Road segment is 2/2 UD. The width of each lane is $3.75 \mathrm{~m}$. The width of the road shoulder toward Jember is $2.2 \mathrm{~m}$, while the shoulder width of the road towards Surabaya is $1.5 \mathrm{~m}$.

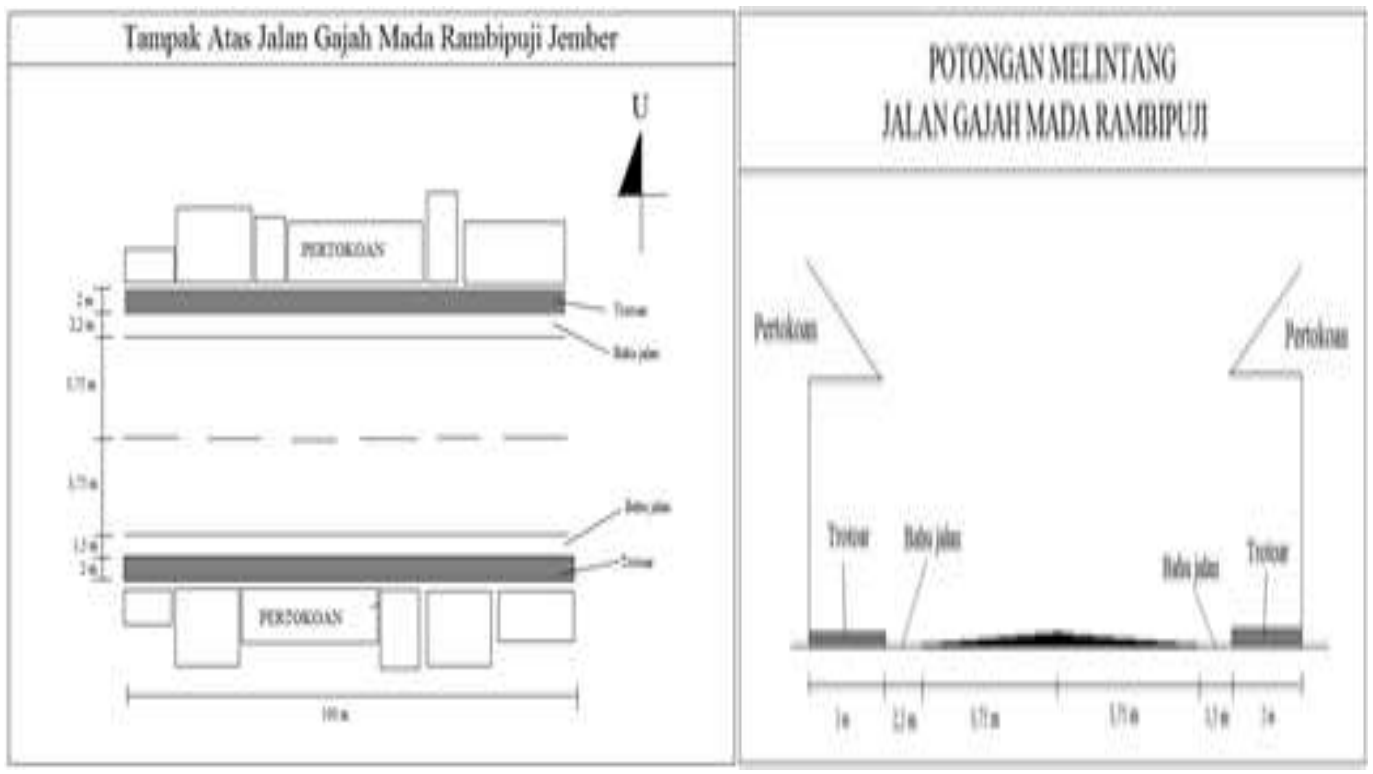

Figure 2. Road geometric of Gadjah Mada St.

\subsection{Traffic volume}

Traffic volume is the number of vehicles passing through a road segment over a period of time. From the survey conducted at 06.00-21.00 it can be seen that the composition of the use of road space, peak hour, and peak hour volume required in the calculation of road performance. Total traffic volume in two directions for 15 hours for MC of 36,679 vehicles, LV 10,449 vehicles, and HV 2,363 vehicles. Figure 1 presents the fluctuations in traffic flow that occurred on Gajah Mada St.

Based on figure 3 above, it can be obtained peak hour traffic. The path to town (towards Jember), peak hour morning at 06.15-07.15, peak hour noon 11.30-12.30, peak hour afternoon 15.15-16.15, and peak evening hours 18.30-19.30. While on the lane out of town (towards Surabaya), peak hour morning at 06.15-07.15, peak hour noon 12.15-13.15, peak hour of the afternoon 15.15-16.15, and peak hours of the night 17.30-18.30. 


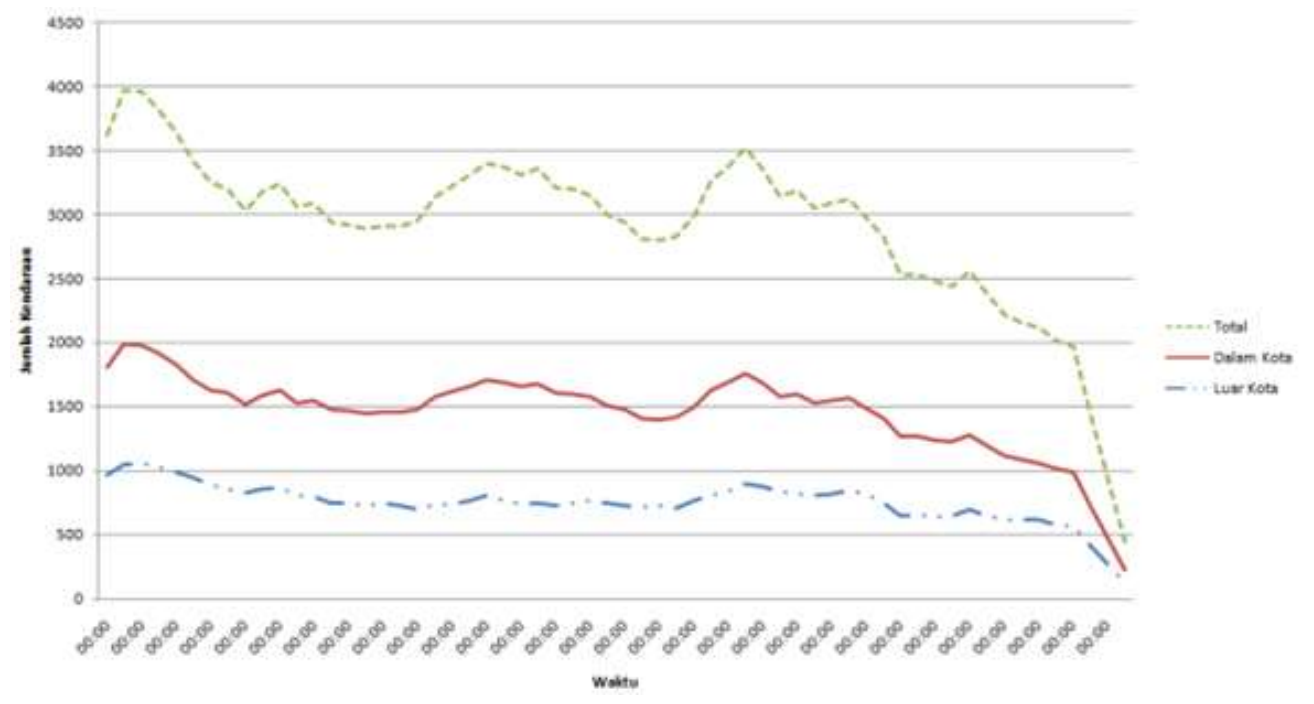

Figure 3. Traffic fluctuations (smp/h)

\subsection{Road performance analysis}

Roadway performance variables include free flow rate, road capacity, degree of saturation, travel speed and service level. The performance of the road segment analyzed with the data obtained in the field is the performance of the road with the street parking (parking on the road body). Performance of roads without the street parking is obtained by adding the effective lane width of the road body section used for parking, so parking vehicles are considered non-existent. The width of effective path on road parking condition is $7 \mathrm{~m}$, and on condition without on street parking is $11,2 \mathrm{~m}$. Comparison of road performance with and without on street parking is shown in table 1 below.

Table 1. Road performance analysis

\begin{tabular}{|c|l|c|c|c|c|c|c|c|c|}
\hline \multirow{2}{*}{ No. } & \multirow{2}{*}{$\begin{array}{l}\text { Variables of } \\
\text { Analysis }\end{array}$} & \multicolumn{2}{|c|}{ Peak Hour } \\
\cline { 3 - 11 } & & \multicolumn{2}{|c|}{ Morning } & \multicolumn{2}{|c|}{ Afternoon } & \multicolumn{2}{c|}{ Evening } & \multicolumn{2}{|c|}{ Night } \\
\hline 1. & $\begin{array}{l}\text { Side friction } \\
\text { classification }\end{array}$ & Low & $\begin{array}{l}\text { Very } \\
\text { Low }\end{array}$ & Medium & Low & Medium & Low & Low & $\begin{array}{c}\text { Very } \\
\text { Low }\end{array}$ \\
\hline 2. & Capacity (C) & 2890 & 3616 & 2832 & 3543 & 2832 & 3543 & 2890 & 3616 \\
\hline 3. & $\begin{array}{l}\text { Degree of } \\
\text { Saturation } \\
\text { (DS) }\end{array}$ & 0.68 & 0.54 & 0.62 & 0.49 & 0.61 & 0.49 & 0.45 & 0.36 \\
\hline 4. & Speed (VLV) & 35 & 40 & 36 & 40 & 36 & 40 & 40 & 43 \\
\hline 5. & $\begin{array}{l}\text { Level of } \\
\text { Service }\end{array}$ & $\mathrm{D}$ & $\mathrm{C}$ & $\mathrm{D}$ & $\mathrm{C}$ & $\mathrm{D}$ & $\mathrm{C}$ & $\mathrm{D}$ & $\mathrm{C}$ \\
\hline
\end{tabular}

Based on table 1, the performance with on street parking and without on street parking showed the capacity increased by $25 \%$, the degree of saturation decreased by $25 \%$, the travel speed increased by $11 \%$, and the level of road service increased from the service level of road $\mathrm{D}$ to Level of service $\mathrm{C}$. This condition occurs because of the reduction on the effective width of the road used for parking. The effective width reduction for a total of 2 lanes is $4.2 \mathrm{~m}$, of $11.2 \mathrm{~m}$ width is effective only $7.5 \mathrm{~m}$. 


\subsection{Parking characteristics}

Parking characteristic is a basic trait that can provide an assessment of parking services and parking problems that occur in the study area [2]. Parking characteristics consist of parking accumulation, parking volume, parking turn over, parking index, parking duration, and parking capacity. Parking characteristics are needed to analyze the operational conditions and design the development of parking lots.

Parking accumulation is the number of vehicles being parked in a place at any given time. Parking volume is the number of vehicles parked in a certain place or parking area for a certain time. The time used is usually one day. The results of parking survey data analysis obtained peak parking hours, accumulation and volume of parking vehicles for motorcycles (MC), light vehicles (LV), and heavy vehicles (HV).

Table 2. Parking characteristics

\begin{tabular}{|c|l|c|c|c|}
\hline \multirow{2}{*}{ No. } & \multirow{2}{*}{ Factor of Analysis } & \multicolumn{3}{|c|}{ Type of Vehicles } \\
\cline { 3 - 5 } & & MC & LV & HV \\
\hline 1. & Peak hour of parking & $10.00-11.00$ & $11.00-12.00$ & $13.30-14.30$ \\
\hline 2. & Parking volume (veh) & 257 & 62 & 10 \\
\hline 3. & Accumulation of parking (veh/h) & 46 & 20 & 5 \\
\hline 4. & Turn over parking (veh/SRP/h) & 0.0997 & 0.45880 & 1.0940 \\
\hline 5. & Duration of parking (minutes) & 15 & 29 & 24 \\
\hline 6. & Capacity of parking (SRP/h) & 689 & 19 & 2 \\
\hline 7. & Parking Index & 0,27 & 2,22 & 8,20 \\
\hline
\end{tabular}

Turnover parking is the rate of parking usage for a certain period of time. The parking turnover rate is obtained from the division between the total numbers of parked vehicles with the number of parking lots available during the observation time. The turn over parking value for MC is $0.0997, \mathrm{LV}$ is 0.4588 , and $\mathrm{HV}$ is 1.0940 . The duration of the parking is the length of time the vehicle is parked on the parking lot. Parking duration is calculated by reducing parking time out with parking admission time. After getting the parking duration of each vehicle and each type of parked vehicle, it can be calculated that the average length of time parking. The average MC parking time was 15 minutes, LV was 29 minutes and $\mathrm{HV}$ was obtained 24 minutes.

Parking capacity is the number of vehicles that can be serviced by a parking lot during service time. Capacity can be calculated by dividing the number of available plots by the average length of parking time. Parking capacity for MC is 689 SRP / hour, LV is 19 SRP / hour, and HV is 2 SRP / hour. Parking index (IP) is calculated by dividing the number of parking vehicles with available parking lots. MC Parking Index obtained 0.27, MC of 2.22, and LV of 8.20. If IP> 1 then the parking requirement exceeds the existing capacity or problems occur. Conversely, if IP $<1$ then the parking needs are still under existing capacity or no problem. The parking for motorcycles has less than one IP, meaning parking space is no problem or still enough to accommodate vehicle parker. Parking for light and heavy vehicles experiences problems because of more than one IP value.

\subsection{The effect of on-street parking on road performance}

The use of parking space is the percentage level of parking space used in a certain time unit. Use of parking spaces can be used to review whether available parking spaces can or do not accommodate parked vehicles. Analysis on the use of parking spaces on the performance of roads in condition when there is on-street parking using correlation analysis 
to determine the strength of the relationship and the form of relationship between two variables. The strength of the relationship between two variables is called the correlation coefficient and is denoted by the symbol "R". The correlation coefficient value will always be between -1 to +1 . The closer to 1 is the expected $R$ value.

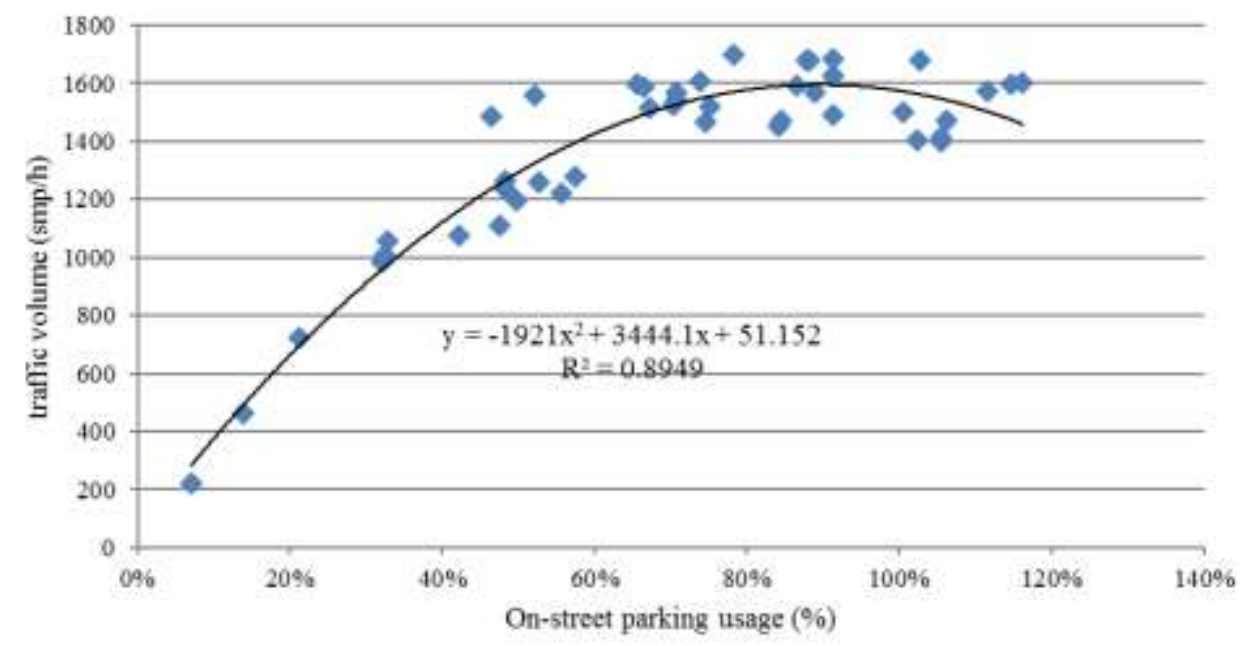

Figure 4. Relationship between parking usage and traffic volume

Based on figure 4, we got value of $\mathrm{R}^{2}$ equal to 0,894 hence value of $\mathrm{R}$ is 0,946 . With $\mathrm{R}$ value equal to 0,946 hence relation of use of parking space with traffic volume included in very strong correlation criterion.

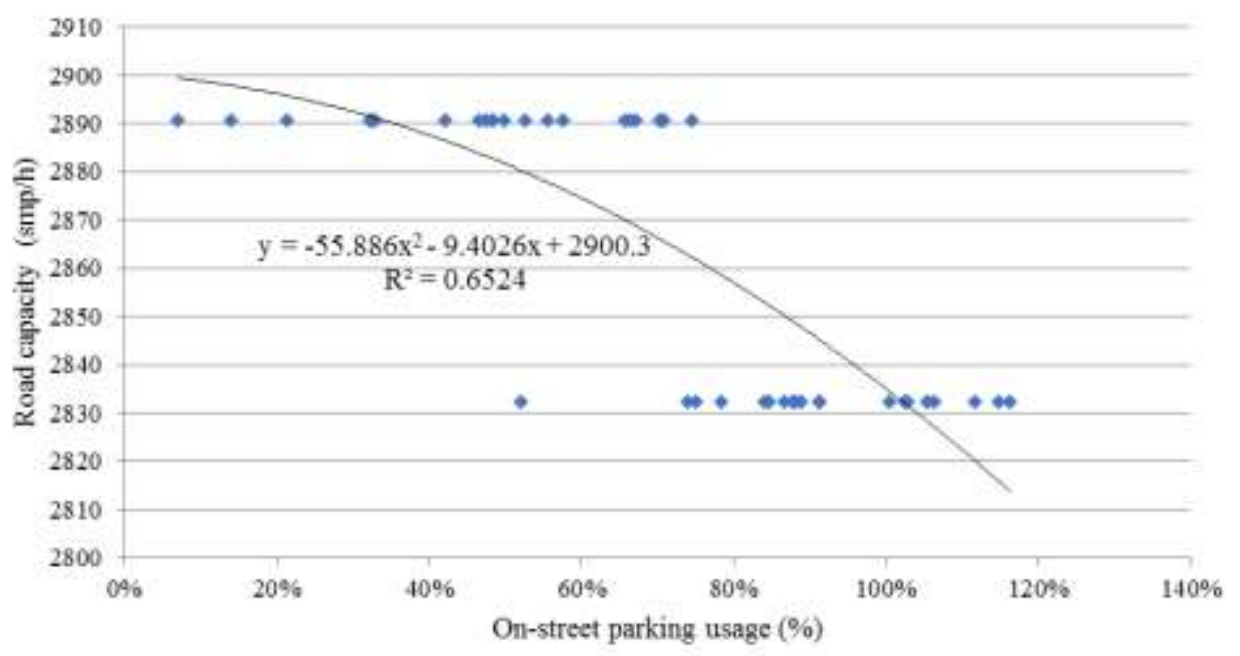

Figure 5. Relationship between parking usage and capacity

Based on figure 5 above got value of $\mathrm{R}^{2}$ equal to 0,659 and value of $\mathrm{R}$ is 0,812 . With $\mathrm{R}$ value equal to 0,812 hence relation of use of parking space with capacity included in very strong correlation criterion. 


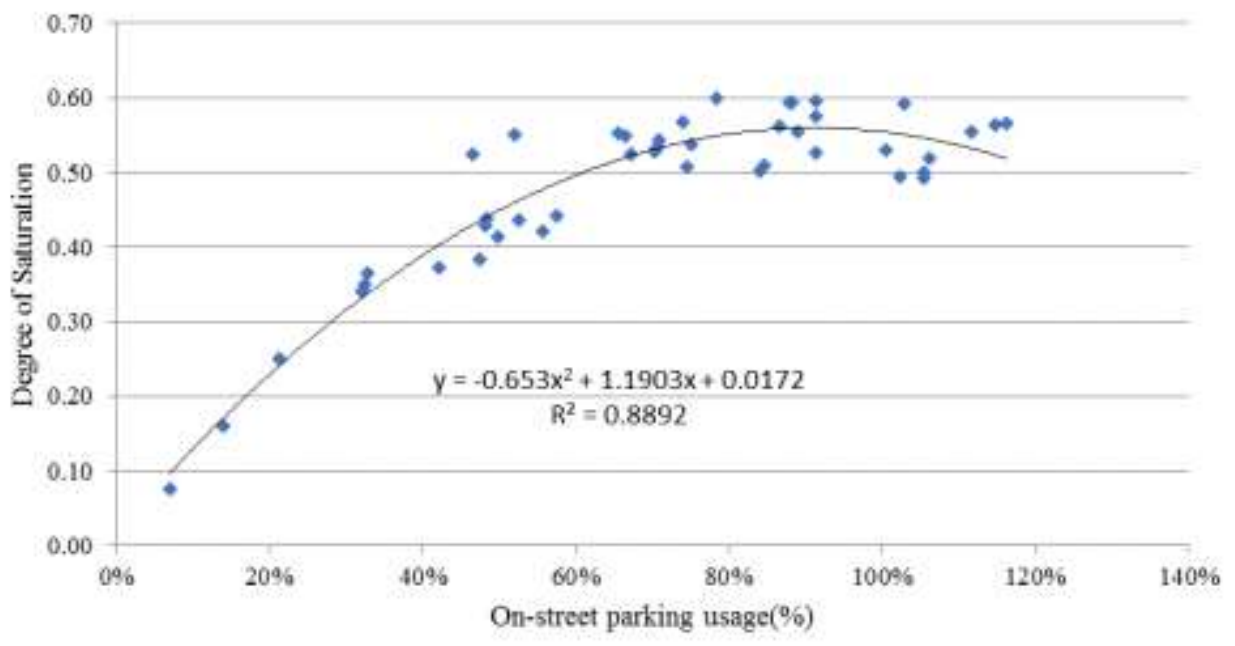

Figure 6. Relationship between parking usage and degree of saturation

Based on figure 6 , we got value of $\mathrm{R}^{2}$ equal to 0,889 , then $\mathrm{R}$ value is 0,943 . With the value of $\mathrm{R}$ the relationship of parking space usage with the degree of saturation included in the criterion is very strong correlation.

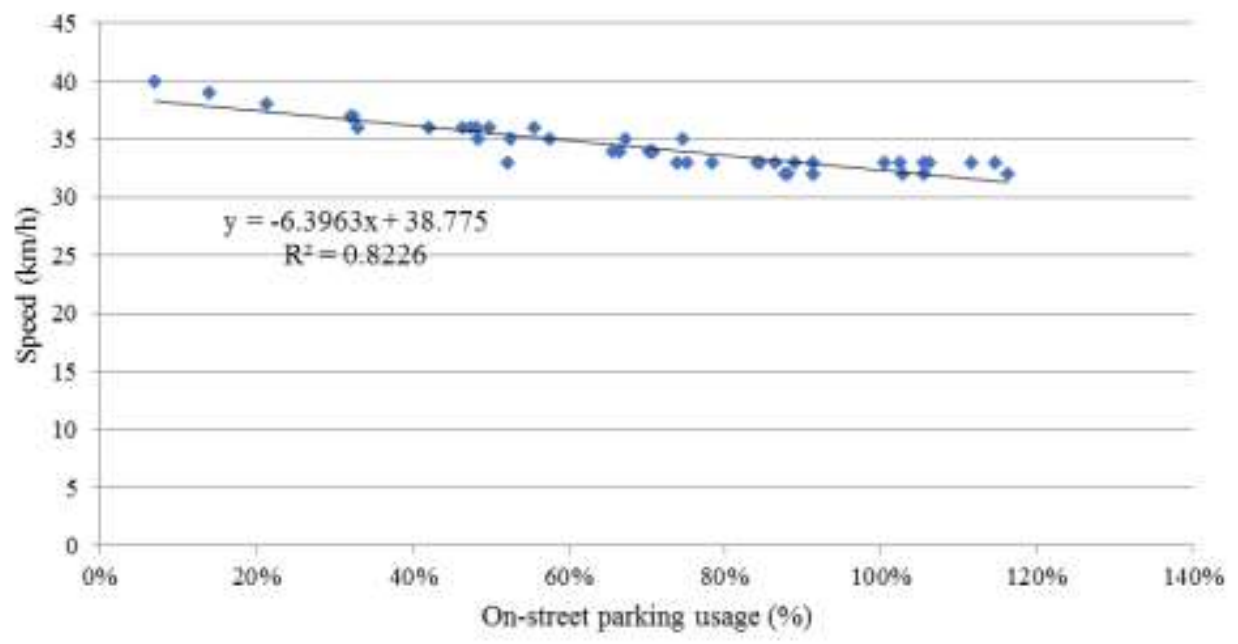

Figure 7. Relationship between parking usage and speed

Based on the figure 7, we obtained value of $R^{2}$ of 0.816 and obtained the value of $R$ is 0.903 . With $\mathrm{R}$ value of 0.903 then the relationship of parking space usage with traffic volume included in high correlation criteria with the form of relationship is negative linear.

\section{Statistical approach}

This statistical test is used to determine whether there is a difference between two pieces of data. This test uses two different test average is Test $\mathrm{Z}$, because the amount of data to be tested is a large data which has 60 data (more than 30 data). Test $\mathrm{Z}$ is conducted to see whether there is a significant difference between road performance when there is on street 
parking and in the absence of on street parking. Road performance tested includes capacity, degree of saturation, and travel speed. Data X1 is a road performance with on street parking and $\mathrm{X} 2$ data is a road performance without on street parking.

Table 3. $z$-test value

\begin{tabular}{|c|c|c|}
\hline Test variable & Reception area & Z-arithmetic \\
\hline Kapasitas & $-2,33>Z>2,33$ & $-3,46$ \\
\hline Derajat kejenuhan & $-2,33>Z>2,33$ & 5,52 \\
\hline Kecepatan tempuh & $-2,33>Z>2,33$ & $-8,12$ \\
\hline
\end{tabular}

The results of the above two-averaging test show that Z-arithmetic is not in the rejection area, so there is a real difference between the test variables (capacity, degree of saturation and speed) when there is on street parking and when there is no on street parking on the real ground $1 \%$. The on street parking has a great effect on road performance (capacity, degree of saturation and speed) that happened.

\section{Conclusions}

From the analysis of the relationship of parking space usage to the performance of the road segment, it can be seen that the use of parking space and road performance has a very strong relationship and strong influence to each other. It can be seen from the correlation coefficient between $0.8-1.00$ which means the relationship is very strong.

\section{References}

1. Purbanto, I Gusti Raka. Karakteristik Parkir Pinggir Jalan (On Street Parking) dan Pengaruhnya terhadap Kinerja Ruas Jalan. Jurnal Ilmiah Teknik Sipil. Vol. 16, No. 2. Denpasar: Universitas Udayana. (2012).

2. Hobbs, F.D. Perencanaan dan Teknik Lalu Lintas. Yogyakarta: Gajah Mada University Press. (1995).

3. Direktorat Jenderal Bina Marga. Manual Kapasitas Jalan Indonesia. Jakarta: Departemen Pekerjaan Umum. (1996).

4. Direktur Jendral Perhubungan Darat. Pedoman Teknis Penyelenggaraan Fasilitas Parkir. Jakarta: Departemen Perhubungan Republik Indonesia. (1996).

5. Departemen Perhubungan. Keputusan Menteri Perhubungan Nomor 14 Tahun 2006 Tentang Manajemen dan Rekayasa Lalu Lintas di Jalan. Jakarta: Departemen Perhbungan Republik Indonesia. (2006).

6. Tamin, O.Z. Perencanaan, Pemodelan, dan Rekayasa Transportasi. Bandung: Penerbit ITB. (2000). 